Travill, A. L. (2008). Socio-economic status and menarcheal age in urban African schoolgirls in the Western Cape, South Africa. South African Journal for Research in Sport, Physical

\title{
Socio-economic status and menarcheal age in urban African schoolgirls in the Western Cape, South Africa
}

\author{
André L. Travill, Richard Madsen, Noël Cameron and Han C. Kemper
}

\begin{abstract}
The impact of different socio-economic levels, height, weight and sum of four skinfolds on the menarcheal age of 302 Black, South African school girls ranging in age from 8 to 17 years was researched. Socioeconomic status was obtained by means of a questionnaire that focused on the education, income, and occupations of the parents of the participants and the accommodation in which they were reared. Menarcheal age was obtained by means of a questionnaire. When restricted to those girls who had reached menarche, the mean age was found to be 14.34 years $(\mathrm{SD}=0.93)$. The application of survival analysis revealed an estimated median age of $\mathbf{1 4 . 2 5}$ years with a $95 \%$ confidence interval estimate of 14.08 and 14.58. Based on the log-rank statistic, significant differences were found in the survival curves of the different SES categories $(p=0.0098)$. It was found that lower SES corresponded to curves having longer survival times, i.e. later ages of menarche. Differences were found in weight $(\mathrm{p}=0.037)$ and in height $(\mathrm{p}=0.0042)$, but no difference in SUM4 ( $\mathrm{p}=0.44)$, between girls who have reached menarche and those who have not.
\end{abstract}

\section{Introduction}

Menarche is primarily important because of its timing within puberty and its sensitivity to environmental changes. Mean age of menarche is considered to be an indicator of population health, well being and socio-economic status, and declines under improved environmental conditions (Henneberg \& Pema, 1992; Cameron \& Nagdee, 1996). Various studies on menarcheal age had been conducted in South Africa. Richardson and Pieters (1977), who studied the growth, menarche and breast development of rural and urban Black South African girls, found the mean age of menarche in urban girls to be 13.0 years and that of rural girls to be $\mathbf{1 4 . 1}$ years. Channing-Pearce and Solomon (1986) found the mean age at menarche of black Johannesburg girls to be 13.9 years. Studies conducted by Cameron and Wright (1990) ( $X=13.2 y r s)$, Henneberg and Louw (1995) ( $X=12.61 \mathrm{yrs}$ ), and Cameron and Nagdee (1996) ( $X=12.4 y r s)$ demonstrated a decline in the menarcheal age of urban girls.

These studies do not report on the impact of different socio-economic levels on the age of menarche. The objective of this study was to assess the mean menarcheal age of Black urban schoolgirls and to research the impact of different socio-economic levels on the age of menarche. 


\section{Methods}

The population from which the sample was drawn is based in Khayelitsha, a township that consists of low cost and informal houses (shacks), situated approximately $26 \mathrm{~km}$ from the centre of Cape Town in South Africa. The township is populated by approximately 500 ooo people of whom about $75 \%$ are first generation urbanised people who mainly come from the rural regions of Transkei and Ciskei and who are still strongly traditionally orientated. Almost the entire economic sector in the township is informal (Lingelethu West City Council, 1992).

Three hundred and two participants, ranging in age from 8 to17 years, were randomly selected from 21 schools in the targeted area. Socio-economic status (SES) was determined by means of a questionnaire which focused on the education, occupation and income of the parents of the participants, and the type of accommodation in which they were living. The socioeconomic variables and weightings are given in Table 1.

Table 1. Socio-economic variables included in calculation of SES (weighting of different levels given in brackets)

\begin{tabular}{|c|c|c|c|c|}
\hline Variable & \multicolumn{4}{|c|}{ Category (Weighting) } \\
\hline $\begin{array}{l}\text { Parental } \\
\text { Education }\end{array}$ & $\begin{array}{l}\text { Standard } 4 \text { and } \\
\text { Below (1) }\end{array}$ & $\begin{array}{l}\text { Standard 5-7 } \\
\text { (2) }\end{array}$ & $\begin{array}{l}\text { Standard 8-10 } \\
\text { (3) }\end{array}$ & Post Matric (4) \\
\hline Income & $\begin{array}{l}\text { Under R2000 } \\
\mathrm{p} / \mathrm{m} \text { (1) }\end{array}$ & $\begin{array}{l}\text { Between } \\
\text { R2000 and } \\
\text { R5000 (2) }\end{array}$ & $\begin{array}{l}\text { More than } \\
\text { R5000 (3) }\end{array}$ & \\
\hline Accommodation & $\begin{array}{l}\text { Back Yard } \\
\text { Room (1) }\end{array}$ & Shack (2) & House (3) & \\
\hline Occupation & $\begin{array}{l}\text { Unemployed } \\
\text { (1) }\end{array}$ & $\begin{array}{l}\text { Unskilled } \\
\text { Labourers (2) }\end{array}$ & $\begin{array}{l}\text { Skilled } \\
\text { labourers (3) }\end{array}$ & Professional (4) \\
\hline
\end{tabular}

The SES scores varied between a minimum of 4 and a maximum of 14 . These scores allowed for regression analysis of SES with the maturity status of the girls. All variables selected loaded well on the SES construct. SES variables together explained $64.9 \%$ of the variances in the SES construct (Table 2).

Table 2. Factor analysis of the SES variables

\begin{tabular}{|l|l|}
\hline Component \\
\hline Income & 0.742 \\
Occupation & 0.711 \\
Parental Education & 0.587 \\
Accommodation & 0.554 \\
\hline Total Variance Explained & $\mathbf{0 . 6 4 9}$ \\
\hline
\end{tabular}

The age of menarche was recorded by means of the recalled age, if age of menarche has already occurred, as well as the status quo procedures. Clearly only those girls who had reached menarche could be included in calculations of the mean and variability of menarcheal age. Thus the data available on menarche status was the age at menarche or the current age of those girls who had not yet reached menarche. From a statistical point 
of view, if the variable of interest is the age at menarche, then the current age of a girl who has not yet reached menarche would be considered a censored observation. Knowing the values for uncensored observations and the value at censoring for those that are censored allows a survival analysis to be carried out. Using the estimated survival curve, one can estimate the median age at menarche for these girls (as well as other percentiles of the distribution). Further, the effect of covariates can be examined. Differences in survival curves for different subgroups can be compared. The height, weight and sum of triceps, biceps, subscapular and suprailiac skinfolds (SUM4) were also recorded for each subject.

The research was approved by the committee on human subjects (medical) of the University of the Witwatersrand (protocol number: M951112).

\section{Results}

The earliest menarcheal age reported was 10.3 years while the latest was 15.9 years although 10 girls within the sample over the age of 15.9 years had still not reached menarche. When restricted only to those who had reached menarche $(n=103)$ the mean age was 14.34 years $(\mathrm{SD}=0.093)$. The application of survival analysis resulted in an estimated median age of 14.25 ( $95 \% \mathrm{CL}=14.08$ to 14.58$)$.

In order to establish whether the survival curves for each of the SES groups were the same, SES was treated as a categorical variable. SES was available for only 149 girls. Due to small numbers in the lowest and highest SES categories the values were combined within groups: 4-5, 8-9 and 10-14. Sufficient numbers were present to treat 6 and 7 as separate categories. The number of subjects per SES category is illustrated in Table 3 . Based on the log-rank statistic, significant differences were found in the survival curves of the different SES categories $(\mathrm{p}=0.0098)$. Table 3 gives the estimated median age at menarche for the various SES categories. It is clear that the lower SES correspond with later ages of menarche. Using the variable SES as a continuous covariate in a Cox proportional hazards model, the coefficient for SES was found to be significantly different from zero $(\mathrm{p}=0.0013)$. This result confirmed the results from the log-rank test.

Table 3. Estimated median age at menarche $\pm 95 \%$ confidence Limits for SES categories

\begin{tabular}{|l|l|l|l|l|}
\hline SES Group & Number & $\begin{array}{l}\text { Estimate of } \\
\text { Median }\end{array}$ & Lower Limit & Upper Limit \\
\hline $4-5$ & 27 & 14.75 & 14.17 & 15.17 \\
6 & 41 & 14.25 & 14.00 & 15.25 \\
7 & 32 & 14.92 & 13.92 & 14.58 \\
$8-9$ & 25 & 13.92 & 13.50 & 15.00 \\
$10-14$ & 24 & 13.58 & 12.75 & 15.00 \\
\hline
\end{tabular}

It was not possible to examine the effects of the variables relating to physical characteristics by using survival analysis, as this would require longitudinal data. An alternative approach was to stratify by age and do comparisons within each age bracket using the extended Mantel-Haenszel test (using age at last birthday). The test is sensitive to mean score location shifts. Marginal significant differences were found in weight $(\mathrm{p}=0.037)$ and a significant difference in height $(\mathrm{p}=0.010)$, but no difference in $\mathrm{SUM}_{4},(\mathrm{p}$ $=0.44$ ) between girls who have reached menarche compared to those who have not. 
Table 4. Heights, weights and SES of girls who have reached Menarche compared to those who have not*

\begin{tabular}{|c|c|c|c|c|c|c|}
\hline Age & $\begin{array}{l}\text { Menarcheal } \\
\text { Status }\end{array}$ & Variable & $\mathrm{N}$ & Mean & $\begin{array}{l}\text { Lower } 95 \% \\
\text { CL for Mean }\end{array}$ & $\begin{array}{l}\text { Upper } 95 \% \\
\text { CL for Mean }\end{array}$ \\
\hline 12 & $\begin{array}{l}\text { Not } \\
\text { Reached }\end{array}$ & $\begin{array}{l}\text { Mass } \\
\text { Stature } \\
\text { SES } \\
\text { Mass } \\
\text { Stature } \\
\text { SES }\end{array}$ & $\begin{array}{r}1 \\
1 \\
1 \\
\\
29 \\
29 \\
19\end{array}$ & $\begin{array}{r}61.20 \\
153.70 \\
12.00 \\
\\
39.09 \\
144.85 \\
6.57\end{array}$ & $\begin{array}{r}37.57 \\
142.75 \\
5.72\end{array}$ & $\begin{array}{r}40.61 \\
146.95 \\
7.43\end{array}$ \\
\hline 13 & $\begin{array}{l}\text { Not } \\
\text { Reached }\end{array}$ & $\begin{array}{l}\text { Mass } \\
\text { Stature } \\
\text { SES } \\
\text { Mass } \\
\text { Stature } \\
\text { SES }\end{array}$ & $\begin{array}{r}7 \\
7 \\
5 \\
\\
23 \\
23 \\
11 \\
\end{array}$ & $\begin{array}{r}55.04 \\
158.70 \\
9.20 \\
\\
43.98 \\
149.74 \\
6.63\end{array}$ & $\begin{array}{r}49.12 \\
153.77 \\
4.77 \\
\\
41.12 \\
146.41 \\
5.28\end{array}$ & $\begin{array}{r}60.95 \\
163.62 \\
13.62 \\
\\
46.83 \\
153.08 \\
7.98\end{array}$ \\
\hline 14 & $\begin{array}{l}\text { Reached } \\
\text { Not } \\
\text { Reached }\end{array}$ & $\begin{array}{l}\text { Mass } \\
\text { Stature } \\
\text { SES } \\
\text { Mass } \\
\text { Stature } \\
\text { SES }\end{array}$ & $\begin{array}{r}19 \\
19 \\
11 \\
\\
11 \\
11 \\
6\end{array}$ & $\begin{array}{r}47.88 \\
154.23 \\
6.54 \\
\\
46.23 \\
153.62 \\
6.83 \\
\end{array}$ & $\begin{array}{r}45.29 \\
151.96 \\
5.67 \\
\\
43.53 \\
151.01 \\
3.62 \\
\end{array}$ & $\begin{array}{r}50.47 \\
156.51 \\
7.41 \\
\\
48.94 \\
156.23 \\
10.04\end{array}$ \\
\hline 15 & $\begin{array}{l}\text { Reached } \\
\text { Not } \\
\text { Reached }\end{array}$ & $\begin{array}{l}\text { Mass } \\
\text { Stature } \\
\text { SES } \\
\text { Mass } \\
\text { Stature } \\
\text { SES } \\
\end{array}$ & $\begin{array}{l}24 \\
24 \\
14 \\
\\
6 \\
6 \\
5 \\
\end{array}$ & $\begin{array}{r}53.07 \\
155.23 \\
7.07 \\
\\
51.78 \\
154.10 \\
6.20 \\
\end{array}$ & $\begin{array}{r}50.01 \\
152.98 \\
5.97 \\
\\
46.88 \\
152.71 \\
5.16 \\
\end{array}$ & $\begin{array}{r}56.13 \\
157.49 \\
8.16 \\
\\
56.67 \\
155.48 \\
7.23 \\
\end{array}$ \\
\hline 16 & $\begin{array}{l}\text { Reached } \\
\text { Not } \\
\text { Reached }\end{array}$ & $\begin{array}{l}\text { Mass } \\
\text { Stature } \\
\text { SES } \\
\text { Mass } \\
\text { Stature } \\
\text { SES } \\
\end{array}$ & $\begin{array}{l}27 \\
27 \\
13 \\
\\
4 \\
4 \\
1\end{array}$ & $\begin{array}{r}59.36 \\
158.08 \\
7.38 \\
\\
61.85 \\
158.60 \\
8.00 \\
\end{array}$ & $\begin{array}{r}56.62 \\
156.43 \\
6.16 \\
\\
53.14 \\
152.51\end{array}$ & $\begin{array}{r}62.10 \\
159.74 \\
8.60 \\
\\
70.55 \\
164.68\end{array}$ \\
\hline 17 & $\begin{array}{l}\text { Reached } \\
\text { Not } \\
\text { Reached }\end{array}$ & $\begin{array}{l}\text { Mass } \\
\text { Stature } \\
\text { SES } \\
\text { Mass } \\
\text { Stature } \\
\text { SES } \\
\end{array}$ & $\begin{array}{r}25 \\
25 \\
8 \\
\\
6 \\
6 \\
3\end{array}$ & $\begin{array}{r}64.51 \\
160.41 \\
7.62 \\
\\
66.83 \\
159.21 \\
5.66 \\
\end{array}$ & $\begin{array}{r}60.26 \\
158.89 \\
5.73 \\
\\
56.53 \\
157.05 \\
4.23 \\
\end{array}$ & $\begin{array}{r}68.76 \\
161.93 \\
9.51 \\
\\
77.13 \\
161.37 \\
7.10 \\
\end{array}$ \\
\hline
\end{tabular}

* None of the girls aged 8 to 11 years $(n=120)$ have reached the age of menarche and are excluded from the above table.

Table 4 illustrates the differences in weight, height and SES for the two sub-groups (menarche reached or not reached) within each single year age range. The girls who have 
reached menarche were, on average, somewhat taller and heavier than the girls who have not reached menarche but they did not have greater total subcutaneous fat measures.

\section{Discussion}

The estimated median age of menarche for the total sample (14.25 years) in the present study was slightly later than the mean age of 14.03 years of Ubombo females (Cameron et al., 1991) and the 14.06 of rural "Cape Coloured" girls reported by Henneberg and Pema (1992). It was also later than the 13.20 years of "well-off" Soweto girls reported by Cameron et al. (1991) but the higher SES girls in the present study demonstrated a similar age at menarche when analysed by survival analysis. Thus the differences found in the survival curves, when SES was treated as a categorical variable, confirmed the hypothesis that the mean age of menarche is related to environmental and socio-economic factors.

The accelerated maturational processes demonstrated by "well-off" urban girls in Soweto (Cameron et al., 1991) were also present in this study. These results reinforce the notion that the health benefits usually associated with urbanisation are realised when they are also accompanied by an improvement of the general socio-economic environment of the growing child.

It is interesting to note that the median age of menarche is almost a year younger than the girls surveyed in rural and urban South African communities between 1960 and 1975 (Tanner, 1978). The decline in menarcheal age and urban-rural differences, were also highlighted by Cameron and Wright (1990), who found a mean age at menarche of 13.2 years in a group of urban black girls "of good socio-economic status". These findings could be indicative of a secular trend towards earlier onset of maturation, which is promoted by improved health and nutritional conditions in the cities. However, generalisations about secular trends are complicated by differences in the SES composition of participants in earlier studies and their geographical locations. The age at menarche found in the present study is noticeably later than the mean ages reported by Jacobs (1984) on a group of urban "Coloured" girls and Visagie (1981), who reported on a group of White urban girls (12.8 and 12 years respectively). The research, on which the latter two results were based, was concluded in an era when "Coloureds" and Whites generally occupied higher political and socio-economic status than Blacks.

Significant differences in height and weight between those who had experienced menarche and those who had not were in accordance with the well recognised fact that early maturing children are taller and heavier than their peers during late childhood and adolescence (Malina and Bouchard, 1991). The fact that no significant differences were found in summed subcutaneous fat values reflects that in this particular sample increased subcutaneous fat values following menarche have not yet been recorded.

\section{Conclusion}

The relationships established in the present study highlight the extent to which the genetic potential for growth and maturation is affected by the environment in which growth takes place. Urbanisation and its associated socio-economic hardship is an ongoing process in developing countries. South Africa's urbanisation rate of $3.5 \%$ has major implications for already over-burdened social and economic support services. 
Khayelitsha is a typical example of the many informal settlements (shanty towns), which sprang up around South African cities when influx control legislation was lifted in 1985. Cities can generally not cope with the housing and services required in these rapidly expanding settlements with the result that these people end up living in informal houses (shacks) with limited services available to them.

It is evident that the realisation of a child's genetic potential for growth and maturation requires the eradication of adverse environmental factors.

\section{Acknowledgement}

The authors gratefully acknowledge the financial support of the Centre for Science Development (CSD), the University of the Western Cape and the South African Institute of Race Relations for their financial support. 


\section{References}

CAMERON, N. \& GETS, B. (1997). Sex differences in the prevalence of obesity in rural African adolescents. International Journal of Obesity, 21: 775-782.

CAMERON, N.; KGAMPHE, J.S. \& LEVIN, Z. (1991). Age at menarche and an analysis of secular trends in menarcheal age of South African black children. Annals of Human Biology, 3: 251-255.

CAMERON, N. \& NAGDEE, I. (1996). Menarcheal age in two generations of South African Indians. Annals of Human Biology, 23: 113-119.

CAMERON, N. \& WRIGHT, C.A. (1990). The start of breast development and age at menarche in South African Black females. South African Medical Journal, 78: 536-539.

CHANNING-PEARCE, S.M. \& SOLOMON, L. (1986). A longitudinal study of height and weight in black and white Johannesburg school children. South African Medical Journal, 70: 743-746.

HENNEBERG, M. \& PEMA, C. (1992). Age at menarche of poor rural "Cape Coloured" girls. South African Medical Journal, 82: 196.

HENNEBERG, M. \& LOUW, G.J. (1995). Average menarcheal age of higher socioeconomic status urban Cape Coloured girls assessed by means of status quo and recall methods. American Journal of Physical Anthropology, 96: 1-5.

JACOBS, T. (1984). A study of the growth and development of boys and girls in the Grassy Park area (7 to 15 years of age). Unpublished Masters thesis. Stellenbosch: University of Stellenbosch.

KEMPER, H.C.G. (1985). Growth, health and fitness of teenagers. In H.C.G Kemper (Ed.), Medicine Science in Sport, vol. 20. Basel: Karger.

LINGELETHU WEST CITY COUNCIL (1992). Khayelitsha profile. Cape Town: Lingelethu West City Council.

MALINA, R.M. \& BOUCHARD, C. (1991). Growth maturation and physical activity. Champaign, IL: Human Kinetics.

RICHARDSON, B.D. \& PIETERS, L. (1977). Menarche and growth. American Journal of Clinical Nutrition, 30: 2088-2091.

SUSANNE, C. (1980). Socioeconomic differences in growth patterns. In F.E. Johnson; A.F. Roche \& C. Susanne (Eds.), Human physical growth and maturation: methodologies and factors. New York, NY: Plenum Press.

TANNER, J.M. (1978). Foetus into man - Physical growth from conception to Maturity. London: Open Books.

VISAGIE, I.H.J. (1981). Antropometriese toetsverskille tussen seuns en dogters 7 tot 15 jaar. Unpublished Masters thesis. Stellenbosch: University of Stellenbosch. 